\title{
Combination of Coagulation-flocculation and Ultrafiltration Processes using Cellulose Acetate Membrane for Wastewater Treatment of Tofu Industry
}

\author{
Sinta Sofiana Putri ${ }^{1}$ and Sutrasno Kartohardjono ${ }^{1, *}$ \\ ${ }^{1}$ Intensification Process Laboratory, Department of Chemical Engineering Universitas Indonesia, Kampus UI Depok 16424, Indonesia.
}

\begin{abstract}
The tofu industry is generally a household-scale industry so that the efficiency of water used and wastewater treatment are mistreated. Wastewater from tofu industry is very hazardous when discharged directly into the aquatic environment as it contains high organic pollutants which is indicated by high concentrations of BOD (biological oxygen demand), COD (chemical oxygen demand), TSS (total suspended solid), TDS (total dissolved solid) and turbidity. The optimization of wastewater treatment process is needed to meet the quality standards set by the government and also needed to obtain more effective and efficient effluent treatment. The aim of this study is to evaluate the performance of combination coagulation-flocculation and ultrafiltration processes for tofu industry wastewater treatment. The process of pretreatment coagulation and flocculation using poly aluminum chloride (PAC) was conducted to extend the life of the ultrafiltration membrane and improve the performance of ultrafiltration membrane separation. The experimental results showed that TSS and turbidity decreased with precipitation time whereas COD did not significantly change. TDS after coagulation-flocculation has increased due to the addition of PAC. The TSS, TDS, COD and turbidity of wastewater were drastically reduced after experiencing ultrafiltration process. After the ultrafiltration process, the TSS, Turbidity, COD and TDS rejection were $98.8 \%, 98.1 \%, 71.0 \%$ and $50.6 \%$, respectively.
\end{abstract}

\section{Introduction}

Tofu is very popular food in Asian country especially in Japan and Indonesia, and is getting popular in European countries due to the associated health benefits and its suitable price [1]. Generally the tofu factory is a small scale household, so the efficiency of the use of water resources and soybean is still low and the level of waste production is very high. Tofu wastewater is divided into two types based on physical appearance, namely solid waste and liquid waste. The solid waste of tofu factories is generally used as animal feed, while the liquid waste can partly be utilized for the clumping of tofu in subsequent production. However, because the volume of wastewater is very large, generally cannot be reused entirely so that it is discharged into the surrounding waters environment. Wastewater of tofu factories contains high organic compounds. Current treatment has not been able to achieve parameters determined by government regulations, i.e. BOD $<150 \mathrm{mg} / \mathrm{L}$, COD $<275 \mathrm{mg} / \mathrm{L}$, TSS $<100 \mathrm{mg} / \mathrm{L}$, and $p \mathrm{H}$ between 6-9 [2]. Conventional or chemically processed wastewater treatment is difficult as the wastewater contains suspended solids, COD and high concentrations of oil [3].

Several researcher have performed studies to exploit wastewater from tofu industry for denitrification of tail water [4], production of hydrogen [5], a medium for microalgae culture [6] and bioethanol production [7]. Many studies also have been conducted to find alternative methods of tofu effluent treatment that more effective and faster process duration. The combination of coagulation-flocculation and ultrafiltration is present as one of the alternative methods for the processing of tofu liquid waste. Coagulation-flocculation method is conducted as a pretreatment before the ultrafiltration process. The pore size of the membranes used ranges from $0.05 \mu \mathrm{m}-5 \mathrm{~nm}$. All dissolved salts and smaller molecules will pass through the membrane, whereas colloids, proteins, microbiological contaminants, large organic molecules will precipitate in advance through the coagulation-flocculation process. There are two products of the ultrafiltration process, namely permeates containing small components capable of passing through the membrane, and retention containing precipitates $[8$, 9]. This research aims to evaluate the effectiveness of combination coagulation-flocculation and ultrafiltration processes to treat wastewater from tofu industry. The parameters such as settling time and trans-membrane pressure in ultrafiltration processes will be examined their effects on the wastewater treatment performance.

\section{Materials and Methods}

Corresponding author: sutrasno@,che.ui.ac.id 
The wastewater used in the experiment was taken from tofu factory in Lenteng Agung South Jakarta. The $p \mathrm{H}$ of wastewater was adjusted to around 7 by adding appropriate volume of $2.0 \mathrm{M} \mathrm{NaOH}$ solutions prior to flocculation-coagulation process. The coagulant was prepared by dissolving 5 gram of PAC into $200 \mathrm{ml}$ of distilled water. The solution for flocculation-coagulation process was prepared by adding $1 \mathrm{ml}$ coagulant solution into a beaker glass containing $250 \mathrm{ml}$ of wastewater solution. The flocculation-coagulation processes were conducted in Jar Test VELP JLT- 6 at $120 \mathrm{rpm}$ for 2 minutes and then $40 \mathrm{rpm}$ for 10 minutes. The solution from the flocculation-coagulation processes were placed for 30 minutes and then were filtered using BIPMED BI filter paper sized $10 \mu \mathrm{m}$. The filtrate was used as a feed solution into ultrafiltration (UF) process. The UF membrane used was cellulose acetate hollow fiber module with MWCO of $20 \mathrm{kDa}$. The pressurized air was used to create the Trans membrane pressure during the ultrafiltration process. The observed parameters such as $p \mathrm{H}$, TSS, TDS, COD, dissolved oxygen (DO) and turbidity were measured for the wastewater before and after the flocculation-coagulation processes and after ultrafiltration process. TSS, DO and turbidity were measured using Colorimeter DR/890, $\mathrm{pH}$ and DO was measured using Hanna combo $\mathrm{pH}$ and EC, and COD was measured using Spectrophotometer UV-Vis BEL UVMS1 single beam. The schematic diagram of the experiment is presented in Fig. 1.

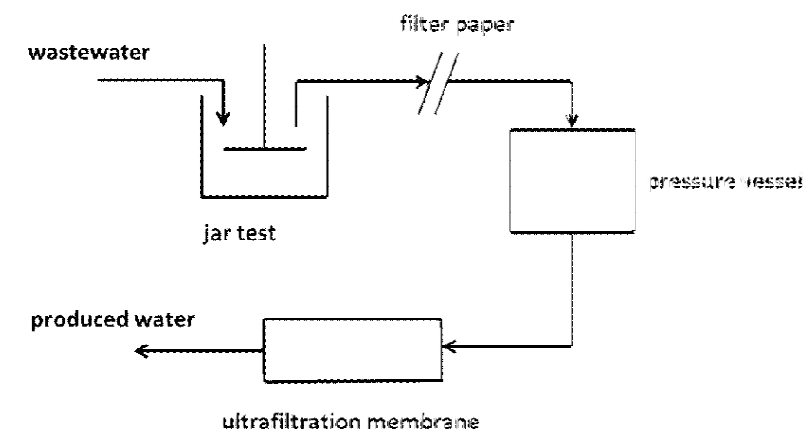

Fig. 1. Schematic diagram of experimental set up.

\section{Results and Discussion}

Table 1 presents the characteristics of tofu wastewater used in the experiments. It can be seen from Table 1 that COD of wastewater are much higher than required by the Government Regulation.

Table 1. Physicochemical characteristics of the tofu wastewater used in the study.

\begin{tabular}{|l|c|c|}
\hline $\begin{array}{c}\text { Observed } \\
\text { Parameters }\end{array}$ & $\begin{array}{c}\text { Concentration } \\
\text { range }\end{array}$ & $\begin{array}{c}\text { Government } \\
\text { Regulation [6] }\end{array}$ \\
\hline$p \mathrm{H}$ & $3.6-3.8$ & $6.0-9.0$ \\
\hline TDS (mg/L) & $910-1040$ & 2000 \\
\hline TSS $(\mathrm{mg} / \mathrm{L})$ & $286-365$ & 100 \\
\hline Turbidity $(\mathrm{FAU})$ & $370-523$ & 25 \\
\hline COD $(\mathrm{mg} / \mathrm{L})$ & $7417-7857$ & 275 \\
\hline BOD $(\mathrm{mg} / \mathrm{L})$ & 2900 & 150 \\
\hline
\end{tabular}

Before pretreatment of coagulation-flocculation, the $p \mathrm{H}$ of wastewater was neutralized in order to optimize the effect of on the coagulant. After the process of coagulation-flocculation, the $p \mathrm{H}$ of wastewater slightly decreased as demonstrated in Figure 2. However, the settling time relatively has no effect on the change of the $p \mathrm{H}$ of the wastewater.

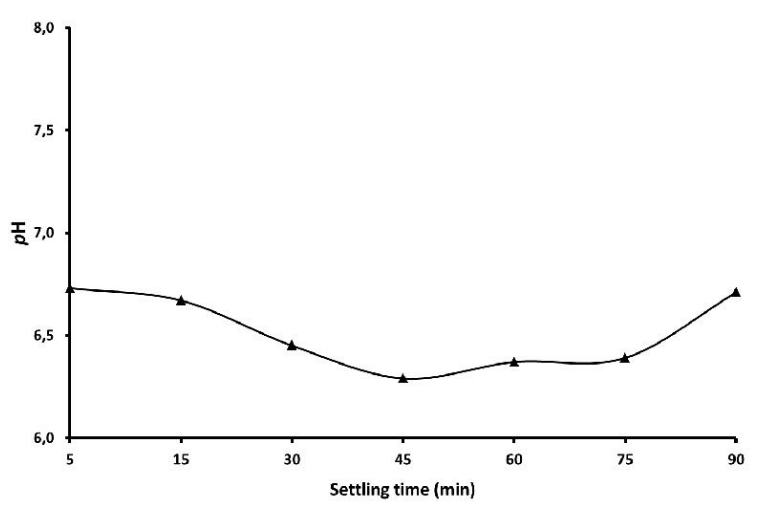

Fig. 2. $p \mathrm{H}$ of wastewater after pretreatment as a function of settling time.

The TSS after pre-treatment of coagulationflocculation and precipitation in the range of 5 minutes to 90 minutes of settling time is shown in Figure 3. There was a decrease in TSS from $197 \mathrm{mg} / \mathrm{L}$ to 170 $\mathrm{mg} / \mathrm{L}$ in the range of 5 to 30 minutes. In the range 30 to 75 minutes there was an increase of TSS from $170 \mathrm{mg} / \mathrm{L}$ to $176 \mathrm{mg} / \mathrm{L}$, which may occur due to the broken of the flock that has been formed. The phenomenon of flock broken may occur due to the disruption of flow on the effluent, so that the flock becomes decomposed again and increases the TSS. Furthermore, in the range of 75 to 90 minutes the TSS relatively constant. The TSS rejection increased and relatively constant in the settling time range 5 to 30 minutes and 30 to 90 minutes, respectively. In this pretreatment, the TSS is still higher than Government Regulation.

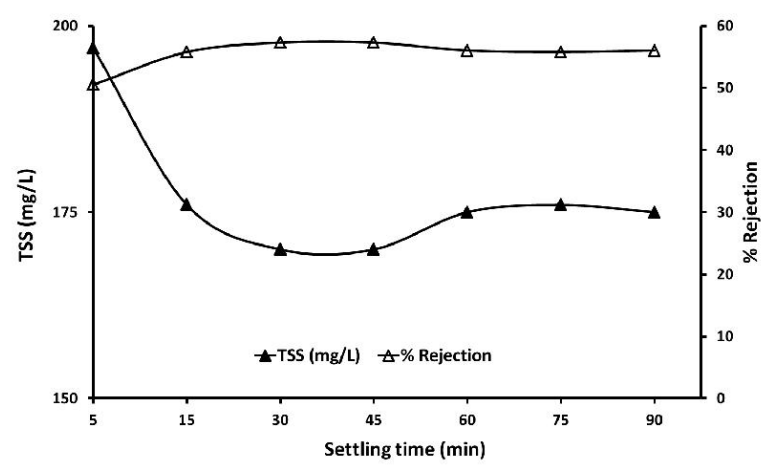

Fig. 3. TSS and TSS rejection after pretreatment as a function of settling time.

The wastewater turbidity in general decreased after coagulation-flocculation pretreatment using PAC as coagulant as presented in Figure 4. The wastewater turbidity decreased in the range of 5 to 30 minutes of settling time from 235 NTU to 210 NTU. In the range of 
30 to 60 minutes the turbidity increased from 210 NTU to $218 \mathrm{NTU}$ and decreased again in the range of 60 to 90 minutes to 208 NTU. The turbidity rejection only significant occurred in the range of 5 to 30 minutes of settling time, while in the range of 30 to 90 minutes the turbidity relatively constant.

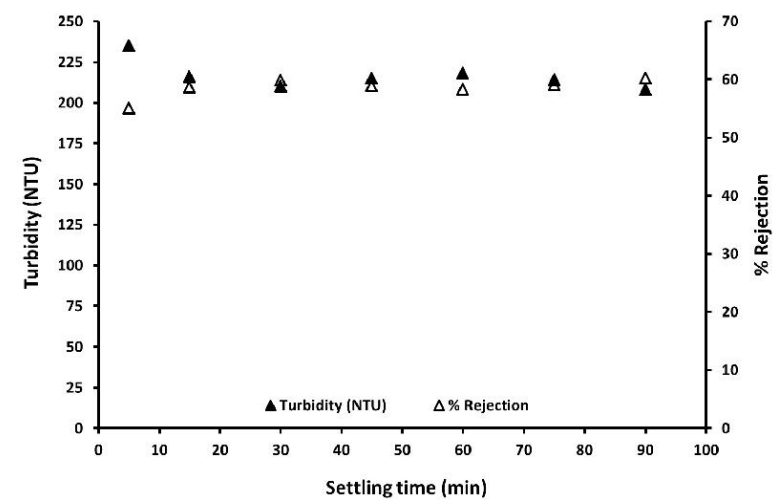

Fig. 4. Turbidity and turbidity rejection after pretreatment as a function of settling time.

COD of the tofu wastewater after coagulationflocculation pretreatment showed a decrease in the range of 5 to 30 minutes settling time, and relatively constant in the range of 30 to 90 minutes as shown in Figure 5. Flocculation treatment with $40 \mathrm{rpm}$ leads to shorter particle spacing so that the attraction between the particles becomes increased and dominant compared to their repulsive forces, resulting greater contact and collision between particles. This flock will aggregate and when the flock growth is maximized (mass and size), these flocks will settle to the bottom of the flask due to the gravitational force effect, resulting two layers, the clearer water layer at the top and the slurry at the bottom which is a colloid that has been destabilized so as to decrease the value of COD. The efficiency of COD rejection increased from $23.6 \%$ to $32.2 \%$ in the settling time range of 5 to 30 minute and relatively constant thereafter. This showed that the optimum settling time for the decrease of COD was 30 minutes, which were similar to those obtained on TSS and turbidity parameters.

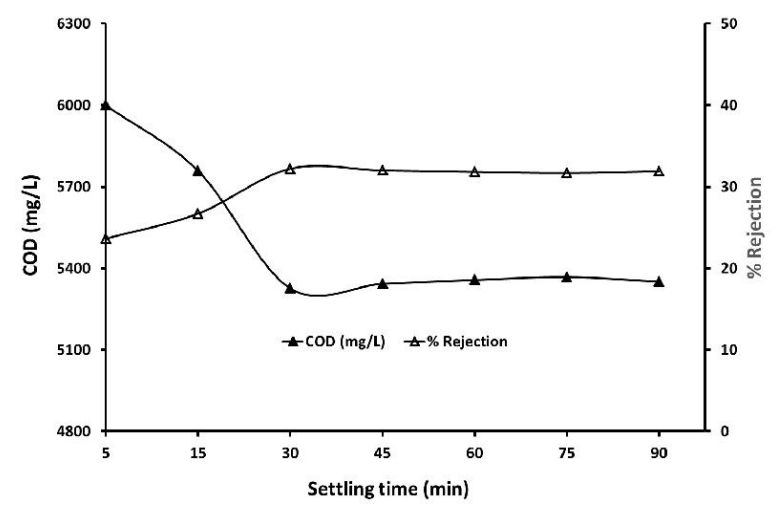

Fig. 5. COD and COD rejection after pretreatment as a function of settling time.
Total Dissolved Solid (TDS) is one of the parameters that can be used for water quality analysis, which is related to the quantity of materials in water that can pass a filter size of $2 \mu \mathrm{m}$. The TDS in the initial sample of the tofu wastewater was increased after the initial treatment of coagulation-flocculation as shown in Figure 6. The increase of TDS occurred due to $p \mathrm{H}$ adjustment of wastewater to 7 prior to the pretreatment of coagulationflocculation. The $p \mathrm{H}$ of wastewater was increased by adding $2 \mathrm{M} \mathrm{NaOH}$ solution. The treatment increased wastewater conductivity, which had an effect on increasing TDS. TDS after the pretreatment can increase significantly due to the relatively low $p \mathrm{H}$ of the wastewater, which was about 3.6-3.8, so there was a need to add enough bases to neutralize it. In addition, the increase in TDS was also due to the addition of coagulant PAC. In general, the TDS increased as a result of increasing the number of solute particles or ions. $\mathrm{NaOH}$ is a strong base, so it can increase the electrolyte properties in the wastewater.

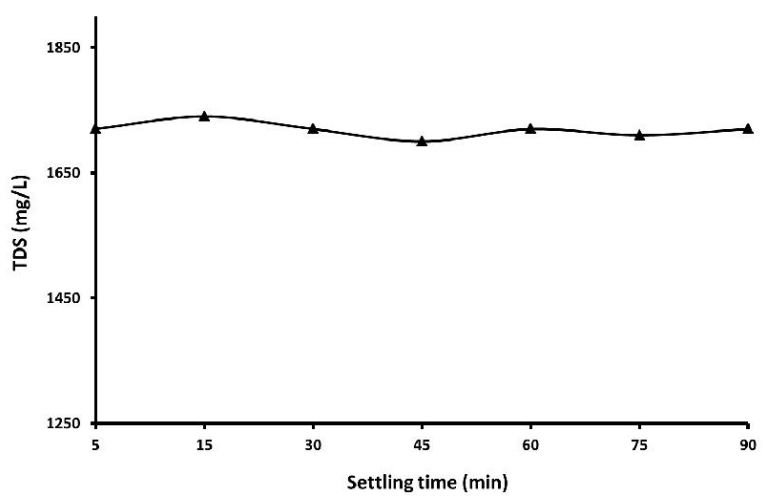

Fig. 6. TDS after pretreatment as a function of settling time.

Based on the $p \mathrm{H}$, TSS, COD, turbidity and TDS parameters as shown in Fig. 2 to Fig. 6, it can be determined that the optimum condition of settling time is 30 minutes. At this time, the flock has been completely deposited. This condition was used in subsequent studies with further treatment in ultrafiltration process using cellulose acetate membranes. The feed water in the ultrafiltration process is the wastewater of the tofu industry after experiencing pretreatment of coagulationflocculation. The wastewater flowed through the lumen side of the membrane fibers and the permeate liquid flowed through the shell side of the membrane module. Dead-end system was used in this study due to relatively limited wastewater and pressure vessel volume of only $2.5 \mathrm{~L}$. The fluxes from the membrane module were observed on five trans-membrane pressures (TMP) variations and resulted in a proportional relationship between the flux and the TMP, i.e. the higher the TMP the higher the flux as demonstrated in Figure 7. The higher the TMP, the higher the driving force of the wastewater to pass through the membrane fiber. Smaller particles than $20 \mathrm{kDa}$ will pass, while larger particles will be retained in the lumen fibers. 


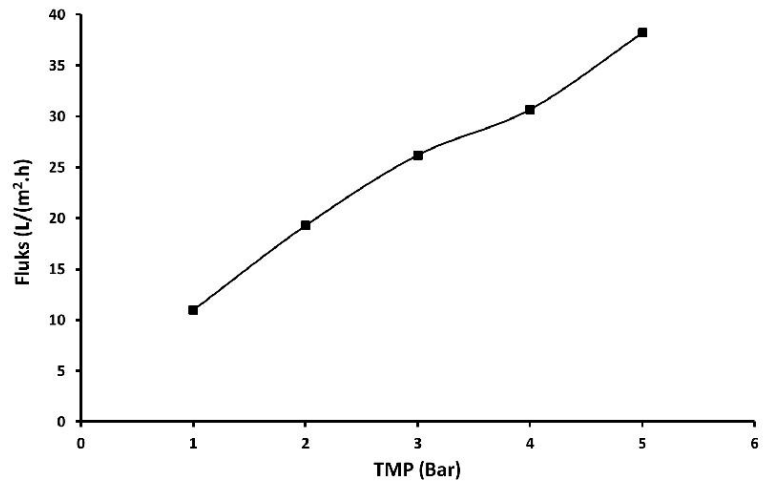

Fig. 7. Flux of ultrafiltration process as a function of TMP.

The $p \mathrm{H}$ of produced water after ultrafiltration process as a function of TMP is presented in Fig. 8. The $p \mathrm{H}$ of produced water relatively did not change during ultrafiltration process and the value is still the range of $p \mathrm{H}$ recommended by the National Environmental Quality Standard.

Changes in TSS of wastewater after ultrafiltration process are presented in Figure 9. TSS decreased drastically with increasing TMP in ultrafiltration process with removal efficiency higher than $94 \%$. In general, the TSS of the produced water from ultrafiltration process was much smaller than the National Environmental Quality Standard, which is $100 \mathrm{mg} / \mathrm{L}$. The similar phenomena also occurred for Turbidity, COD and TDS as shown in Figure 10-12. The Turbidity and the TDS of the product water from ultrafiltration process were smaller than the National Environmental Quality Standard, but the COD was still higher than the National Environmental Quality Standard. The high of COD value is most probably due to ion $\mathrm{Na}^{+}$in the produced water that cannot be separated by the ultrafiltration process. The ion $\mathrm{Na}^{+}$was added in the wastewater for $p \mathrm{H}$ adjustment before pretreatment coagulation-flocculation process in the form of $2 \mathrm{M} \mathrm{NaOH}$ solution. The ion $\mathrm{Na}^{+}$ only can be separated using reverse osmosis (RO) membrane.

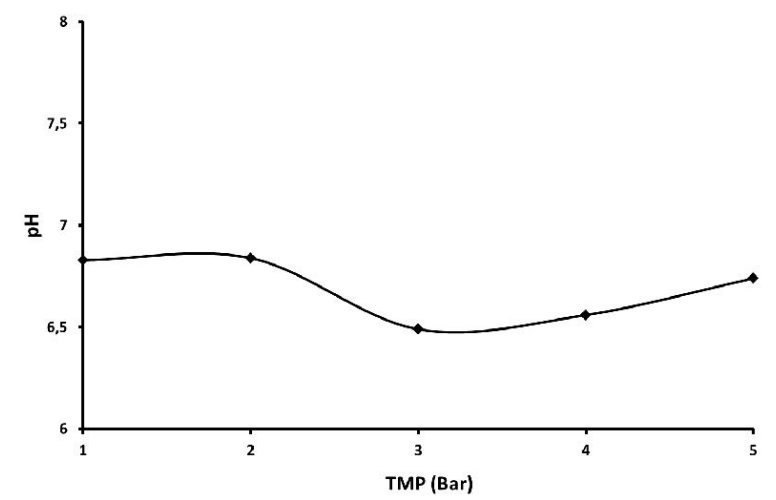

Fig. 8. $p \mathrm{H}$ of produced water from ultrafiltration process as a function of TMP.

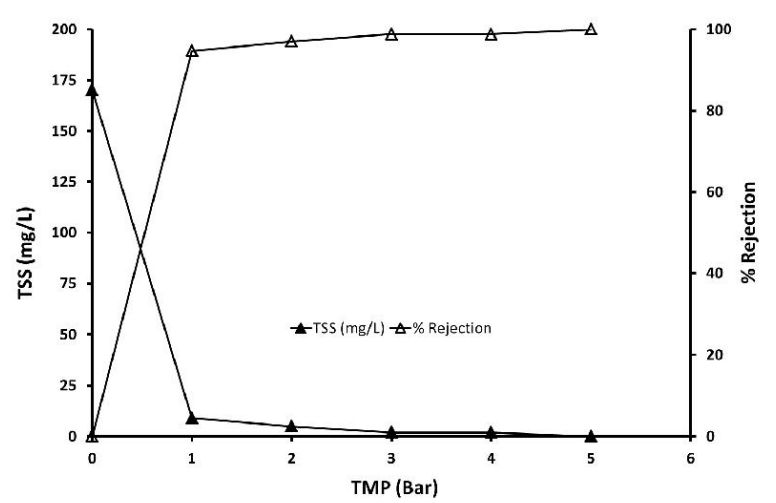

Fig. 9. TSS and TSS rejection of produced water from ultrafiltration process as a function of TMP.

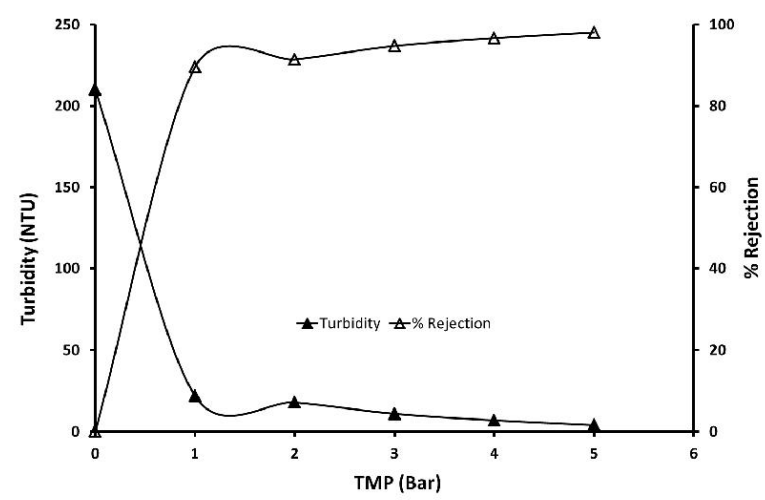

Fig. 10. Turbidity and turbidity rejection of produced water from ultrafiltration process as a function of TMP.

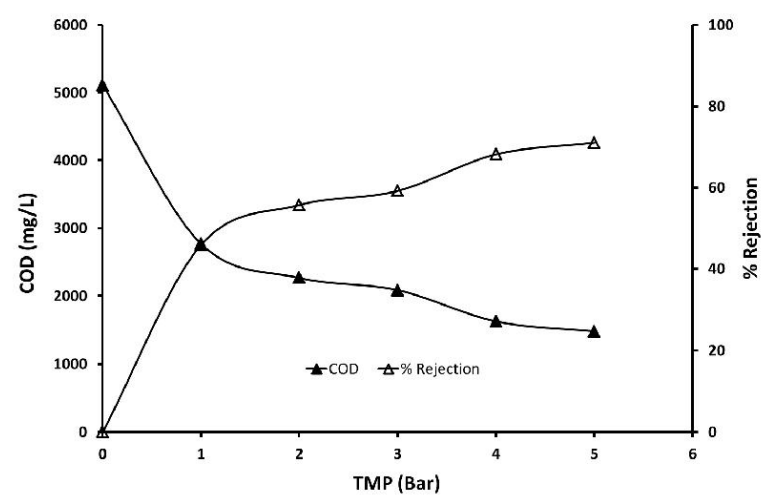

Fig. 11. COD and COD rejection of produced water from ultrafiltration process as a function of TMP.

The results of ultrafiltration process for TMP of 5 Bar together with the National Environmental Quality Standard are presented in Table 2. It can be seen that all parameters except COD meet the requirements of the National Environmental Quality Standard. The high value of COD in the water produced is mainly due to the presence of $\mathrm{Na}^{+}$ions, which cannot be separated on the ultrafiltration unit because the ionic size is still much smaller than the pore diameter of the ultrafiltration membrane. The higher the COD means more oxygen is required for pollutants present in wastewater to be oxidized through chemical reactions. Water with high 
COD content is not desirable for fisheries or agricultural purposes. $\mathrm{Na}^{+}$ions can only be separated using ultrafiltration membrane.

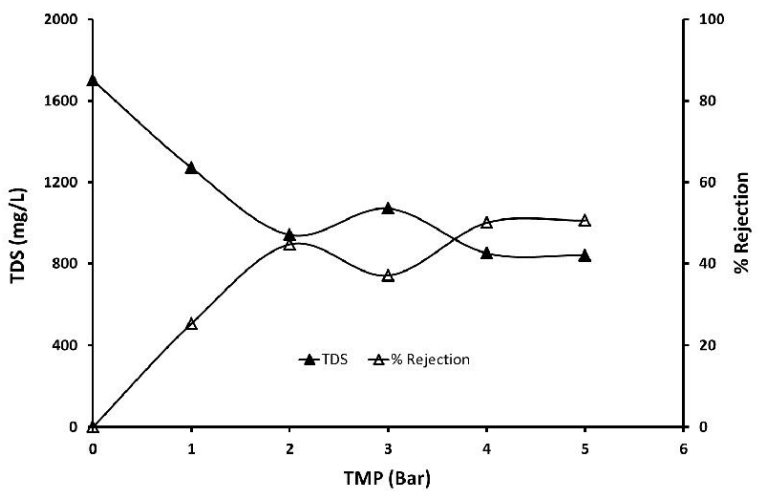

Fig. 12. TDS and TDS rejection of produced water from ultrafiltration process as a function of TMP.

Table 2. The characteristics of the produced water by ultrafiltration process.

\begin{tabular}{|l|c|c|}
\hline $\begin{array}{c}\text { Observed } \\
\text { Parameters }\end{array}$ & $\begin{array}{c}\text { After } \\
\text { Ultrafiltration }\end{array}$ & $\begin{array}{c}\text { Government } \\
\text { Regulation [6] }\end{array}$ \\
\hline$p \mathrm{H}$ & 6.7 & $6.0-9.0$ \\
\hline TDS $(\mathrm{mg} / \mathrm{L})$ & 840 & 2000 \\
\hline TSS $(\mathrm{mg} / \mathrm{L})$ & 0 & 100 \\
\hline Turbidity $(\mathrm{FAU})$ & 4 & 25 \\
\hline COD $(\mathrm{mg} / \mathrm{L})$ & 1481 & 275 \\
\hline BOD $(\mathrm{mg} / \mathrm{L})$ & 9.6 & 150 \\
\hline
\end{tabular}

\section{Conclusions}

The study has been performed to evaluate the combination of coagulation-flocculation and ultrafiltration processes to treat wastewater from tofu industry. The parameters such as $p \mathrm{H}$, TSS, COD, turbidity and TDS were used as as tools for measuring the success of the combination of coagulationflocculation and ultrafiltration processes. The experimental results showed that all parameters except COD meet the requirements of the National Environmental Quality Standard. The high of COD value is most probably due to ion $\mathrm{Na}^{+}$in the produced water that cannot be separated by the ultrafiltration process.

The authors are appreciative to the support from PITTA Project provided by the Directorate of Research and Public Service Universitas Indonesia through Contract No . 2542/UN2.R3.1/HKP.05.00/2018.

\section{References}

1. F. Belén, J. Sánchez, E. Hernández, J.M. Auleda, M. Raventós. J. Food. Eng. 110, 364-373 (2012).

2. Ministerial Regulation of the Ministry of Environment No. 5 (2011).

3. W. Maria, K. D. Cindika, and A. Nita. Jurnal Teknologi Kimia dan Industri, 2, 295-307 (2013).
4. Z. Xue, C. Wang, J. Cao, J. Luo, Q. Feng, F. Fang, C. Li, Q. Zhang. Biochem. Eng. J. 132, 217-224 (2018).

5. H. Zhu, T. Suzuki, A. A. Tsygankov, Y. Asada, J. Miyake. Int. J. H. En. 24, 305-310 (1999).

6. S.-K. Wang, X. Wang, J. Miao, and Y.-T. Tian, Biores. tech. 253, 79-84 (2018).

7. F. Febrianti, K. Syamsu, M. Rahayuningsih. Int. J. of. Tech. 8(5), 898-908 (2017).

8. J. Mulder, Basic principles of membrane technology: Springer Science \& Business Media, 2012.

9. V. Doraisammy, G. S. Lai, S. Kartohardjono, W. J. Lau, K. C. Chong, S. O. Lai, H. Hasbullah, A.F. Ismail, Can. J. Chem. Eng. 96, 1612-1619 (2018). 